\title{
A new miniature of Xenurobryconini (Characiformes: Characidae) from the rio Tapajós basin, Brazil
}

\author{
Marina Barreira Mendonça1, Luiz Antônio Wanderley Peixoto², \\ Guilherme Moreira Dutra ${ }^{1,3}$ and André Luiz Netto-Ferreira ${ }^{1}$
}

\begin{abstract}
A new species of Xenurobrycon is described from tributaries of the rio Tapajós, Pará, Brazil. It is diagnosed from all congeners by the dark color of the posterior half of both caudal-fin lobes, the presence of infraorbitals one, two, and three, the presence of a set of lamellar processes on eighth principal caudal-fin ray of mature males, the presence of bony hooks similar in size or decreasing posteriorly on last unbranched and first 9-12 branched anal-fin rays of mature males, the presence of only conical teeth on both jaws, the lack of the adipose fin and the presence of 15-18 predorsal scales. The description of the new species increases the number of species in Xenurobrycon to six. An updated key to the species of the genus is provided.

Uma espécie nova de Xenurobrycon é descrita de tributários do rio Tapajós, Pará, Brasil. Esta é diagnosticada de todas as congêneres pela coloração escura da metade posterior de ambos os lobos da nadadeira caudal, pela presença dos infraorbitais um, dois e três, pela presença de um conjunto de processos laminares no oitavo raio principal do lobo inferior da nadadeira caudal em machos maduros, pela presença de ganchos no último raio indiviso e primeiros 9-12 raios ramificados da nadadeira anal em machos maduros, estes com tamanho similar ou diminuindo de tamanho posteriormente, pela presença de apenas dentes cônicos nas maxilas, pela ausência de nadadeira adiposa e pela presença de 15-18 escamas pré-dorsais. A descrição da espécie nova aumenta o número de espécies em Xenurobrycon para seis. Uma chave atualizada para as espécies do gênero é fornecida.
\end{abstract}

Keywords: Key to species, Miniaturization, Ostariophysi, Sexual dimorphism, Taxonomy.

\section{Introduction}

The Xenurobryconini (Characidae: Stevardiinae) traditionally comprises seven inseminating genera (Weitzman \& Fink, 1985; Weitzman \& Menezes, 1998): Argopleura Eigenmann, Chrysobrycon Weitzman \& Menezes, Iotabrycon Roberts, Ptychocharax Weitzman, Fink, Machado-Allison \& Royero, Scopaeocharax Weitzman \& Fink, Tyttocharax Fowler, and Xenurobrycon Myers \& Miranda Ribeiro. The monophyly of this tribe was originally proposed by Weitzman \& Fink (1985), based on sexually dimorphic characters. Such phylogenetic definition was subsequently adjusted by Weitzman et al. (1994) to include the genus Ptychocharax in the group, although any explicit phylogenetic hypothesis was provided. The later addition of Chrysobrycon restricted the definition of the Xenurobryconini to the presence of a single pouch scale with or without hypertrophied radii in adult males, an ambiguously optimized character in the phylogenetic hypothesis by Weitzman \& Menezes (1998), giving little support to the new composition of the group. With effect, the recent study by Thomaz et al. (2015), questioned the monophyly of the Xenurobryconini, since their data strongly refuted Chrysobrycon (nested within the Stevardiini) and Argopleura (now an incertae sedis taxon) as members of the tribe, as previously proposed by Weitzman \& Fink (1985), Weitzman et al. (1994) and Weitzman \& Menezes (1998).

\footnotetext{
${ }^{1}$ Museu Paraense Emílio Goeldi, Avenida Perimetral, 1901, caixa postal 399, 66077-530 Belém, Pará, Brazil. (MBM) barreira.mm@ gmail.com (corresponding author); (ALN-F) alnferreira@gmail.com

${ }^{2}$ Museu de Zoologia da Universidade de São Paulo, caixa postal 42494, 04218-970 São Paulo, São Paulo, Brazil. (LAWP) luizwp@yahoo. com.br

${ }^{3}$ Laboratório de Evolução e Desenvolvimento de Vertebrados, Centro de Genômica e Biologia de Sistemas, Universidade Federal do Pará, Rua Augusto Corrêa, caixa postal 479, 66075-900 Belém, Pará, Brazil. (GMD) guilhermedutr@yahoo.com.br
} 
The definition of the genus Xenurobrycon is based on the presence of several secondary sexual characters in mature male specimens (Weitzman \& Fink, 1985). This involves mainly their conspicuously larger size and the anterior displacement position of the pelvic fin, along with modifications to the pelvic girdle; the double ligamentous attachment of the pouch scale; and the interrupted principal caudal-fin rays (sensu Weitzman \& Fink, 1985 usually the median-most ray of upper and lower caudal-fin lobes). The genus currently consists of five valid miniature species (sensu Weitzman \& Vari, 1988), and a sixth is herein described from the rio Tapajós basin. Its putative relationships among congeners are discussed and an updated key to identify all Xenurobrycon species is also provided.

\section{Material and Methods}

Counts and measurements follow Fink \& Weitzman (1974). Measurements were taken point-to-point with aid of scaled eyepiece reticule. Standard length (SL) is presented in $\mathrm{mm}$ and other measurements are expressed as proportions of SL, except for subunits of head which are expressed as proportions of head length (HL). Descriptions of meristic data are accompanied by frequency counts in parentheses; an asterisk indicates the values of the holotype.

The number of scales along contralateral pelvic fins were counted between the pelvic-fin insertions (at the origin of the first unbranched ray). Numbers of vertebrae, supraneurals, procurrent caudal-fin rays, branchiostegal rays, gill rakers, and teeth were determined from cleared and stained paratypes (c\&s) prepared according to Taylor \& Van Dyke (1985). Vertebrae of the Weberian apparatus were included in the vertebral counts and the compound centrum formed by the first pleural and first ural centra $(\mathrm{PU} 1+\mathrm{U1})$ of the caudal region was counted as a single element. All examined specimens were alcohol preserved, except when indicated by c\&s, specimens preserved in glycerin. The non-type series is represented by damaged specimens. The term "set of lamellar processes" is used to indicate the sum of the paired flange-like processes of Weitzman \& Fink (1985), which are ventral, plus the dorsal processes of the same lepidotrichia segments, or more than one lepidotrichium bearing a flange-like process. Institutional abbreviations follow Ferraris (2007) with addition of the Museu de Ciências Naturais Pontifícia Universidade Católica de Minas Gerais, Belo Horizonte (MCNIP). An identification key of the Xenurobrycon species was modified from Weitzman \& Fink (1985) and Weitzman (1987). Statistical analyses were carried out in R v.3.1.1 software (R Core Development Team, 2012): the packages npsm, Rfit and xlsx were additionally employed (Dragulescu 2014; Kloke \& McKean, 2012; 2014a,b). A nonparametric robust ANCOVA and the Wilcoxon regressions were used as the assumptions of normality, required for use of their parametric counterparts, were not met.

\section{Results}

\section{Xenurobrycon varii, new species}

urn:1sid:zoobank.org:act:01A0735B-EB85-46F0-AA9EED8DE7234D37

Figs. 1 and 2; Table 1

Holotype. MPEG 32825, male, 14.2 mm SL, Brazil, Pará, Jacareacanga, Vila de Mamãe Anã, tributary of rio Tapajós, 542’22”S 57²2’30”W, 19 Jan 2013, N. Benone.

Paratypes. All from Brazil, Pará, Jacareacanga, rio Tapajós basin: INPA 48819, 3 males (12.5-14.0 mm SL), 7 females or immatures (11.1-13.7 mm SL), collected with holotype. MCNIP 1678, 3 males (12.5-13.5 mm SL), 7 females or immatures (11.4-13.4 mm SL), rio Tapajós basin, near Vila de Mamãe Anã, 05²'23.5'S 57²2'31.9'W, 2 Oct 2012, N. Benone. MPEG 25239, 9 males (13.1-13.4 mm SL; 3 c\&s), 45 females or immatures (8.4-13.9 mm SL; 3 c\&s), same data as MCNIP 1678. MPEG 25240, 2 females or immatures (13.1-14.6 mm SL), near Vila de São Martins, 06 05'59.7'S 57³9'11.0”'W, 9 Oct 2012, N. Benone. MPEG 25242, 1 male (15.3 mm SL), 2 females or immatures (13.4-13.5 mm SL), near Vila de Penedo, 05³6'40.4'S 5707'16.6”W, 12 Oct 2012, N. Benone. MPEG 25271, 22 females or immatures (10.3-13.2 mm SL), near Vila de Mamãe Anã, 4 Dec 2012, N. Benone. MPEG 26592, 29 males (12.9-14.3 mm SL; $3 \mathrm{c} \& \mathrm{~s}), 47$ females or immatures (10.2-14.4 mm SL; $3 \mathrm{c} \& \mathrm{~s})$, collected with holotype. MPEG 26593, 2 males (16.3-16 mm SL), 2 females or immatures (15.9-16.8 mm SL), Vila de Penedo, 536'40”S 57 7'16”W, 16 Jan 2013, N. Benone. MPEG 26594, 13 males (15.0-15.7 $\mathrm{mm}$ SL; 2 c\&s), 16 females (14.4-16.51 mm SL), Vila de Buburé, 444'10"'S 56³7'19'W, 07 Jan 2013, N. Benone. MPEG 26595, 3 males (15.8-16.0 mm SL), 3 females or immatures (15.2-15.6 mm SL), Vila de Buburé, 442'58'S 56²6’24”'W, 6 Jan 2013, N. Benone. MPEG 27749, 17 males (13.1-14.5 mm SL), 33 females or immatures (9.5-15.0 mm SL), Vila de Mamãe Anã, 542'21.6”'S 57²2’30.0”W, 26 Mar 2013, T. Begot. MPEG 27875, 3 females or immatures (11.2-12.5 mm SL), Vila de São Martins, $6^{\circ} 06^{\prime} \mathrm{S}$ 57³9’W, 29 Mar 2913, T. Begot. MPEG 27920, 2 females or immatures (11.3-12.4 mm SL), Vila de Mamãe Anã, $5^{\circ} 47^{\prime} 49.2^{\prime \prime} \mathrm{S} 57^{\circ} 24^{\prime} 7.2^{\prime \prime} \mathrm{W}, 28$ Mar 2013, T. Begot. MPEG 27937, 3 females or immatures (10.1-11.6 mm SL), Vila de Jatobá, 503'50.4”S 5651'46.80"W, 19 Mar 2013, T. Begot. MPEG 28439, 1 female or immature (12.8 mm SL), Vila de São Martins, 606’22.0”S 57³9’25.2”W, 3 Sep 2013, Ambiental Concremat team. MPEG 28553, 9 males (12.114.6 mm SL), 8 females or immatures (11.3-12.9 mm SL), Vila de Mamãe Anã, 5'42’32.4”S 57²2’30”W, 28 Aug 2013, Ambiental Concremat team. MPEG 28589, 1 female or immature, $12.3 \mathrm{~mm} \mathrm{SL}$, Vila de Penedo, 5'36'11.9"S 57 07'15.6”'W, 25 Aug 2013, Ambiental Concremat team. 
MZUSP 117877, 3 males (12.4-13.6 mm SL), 7 females or immatures (13.2-14.3 mm SL); USNM 436655, 3 males (12.1-13.1 mm SL), 7 females or immatures (11.3-13.1 mm $\mathrm{SL})$, collected with holotype.

Non-types. All from Brazil, Pará, rio Tapajós basin: MPEG 7692, 6 females or immatures (12.2-13.5 mm SL), rio Santa Luzia, Trairão, $05^{\circ} 15^{\prime} 46^{\prime}$ 'S 56 $01^{\circ} 29^{\prime}$ ' W, 12 Jun 2002. MPEG 26591, 6 males (15.0-16.2 mm SL), 3 females or immatures (14.9-17.3 mm SL), Vila de Mamãe Anã, 05'45'52"S 57 16 '58”W, 18 Jan 2013. MPEG 28453, 2 females or immatures (11.1-13.2 mm SL), Vila de Mamãe Anã 546’48.4’S 57¹7'23.9’'W, 30 Aug 2013.

Diagnosis. Xenurobrycon varii is readily distinguished from its congeners by the dark posterior half of both caudal-fin lobes (vs. hyaline) and the absence of infraorbitals 4 and 5 ( $v s$. absence of infraobitals 1, 4 and 5 in $X$. coracoralinae Moreira and presence of infraorbitals 1-5 in X. heterodon Weitzman \& Fink, X. macropus Myers
\& Miranda Ribeiro, X. polyancistrus Weitzman and $X$. pteropus Weitzman \& Fink). The new species is further differentiated from its congeners, except $X$. coracoralinae and $X$. macropus, by the presence of a set of lamellar processes on the eighth principal ray of the lower caudalfin lobe (Figs. 3a, 3b, vs. absence in $X$. heterodon, $X$. polyancistrus and $X$. pteropus). The new species differs from $X$. coracoralinae by the presence of hooks on the last unbranched plus the first $9^{\text {th }}-12^{\text {th }}$ branched anal-fin rays of mature males (Fig. 4a, 4b, vs. hooks present only on last unbranched and first $4^{\text {th }}-5^{\text {th }}$ branched rays). Xenurobrycon varii can be additionally distinguished from $X$. heterodon by the presence of only conical dentary teeth (Fig. $5 v s$. anterior dentary teeth tricuspid). The new species is also differentiated from $X$. polyancistrus by the posterior anal-fin hooks approximately equal or reduced in size posteriorly in mature males (Fig. 4a, 4b, vs. posterior larger anal-fin hooks). Finally, it further differs from $X$. pteropus by the absence of adipose-fin (vs. presence) and greater number of predorsal scales (15-18 vs. 13).

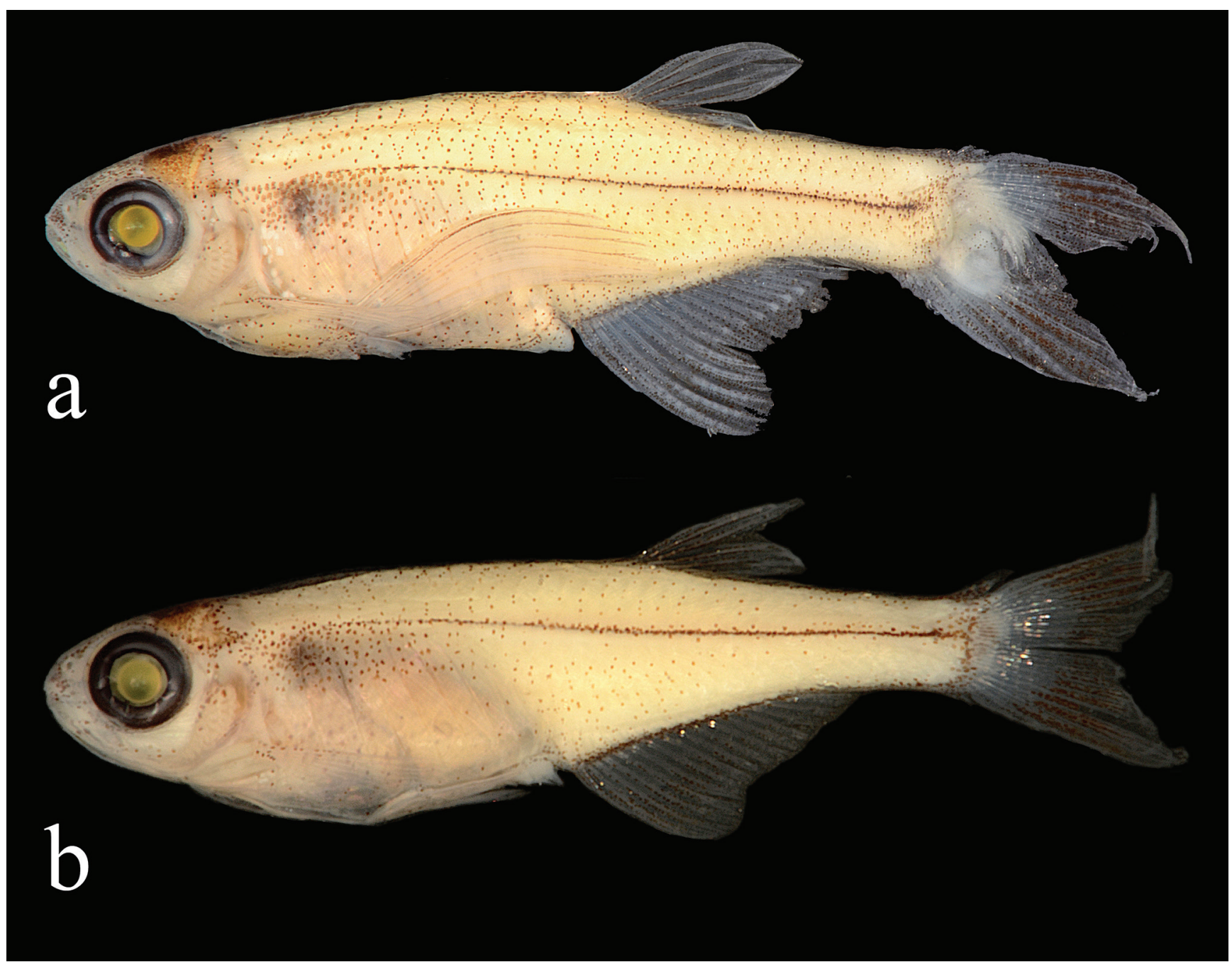

Fig. 1. Xenurobrycon varii, new species, Brazil, Pará, Jacareacanga, Vila de Mamãe Anã, tributary of rio Tapajós. (a) MPEG 32825 holotype, male, $14.2 \mathrm{~mm}$ SL; (b) MPEG 26592, paratype, female, $13.2 \mathrm{~mm}$ SL. 


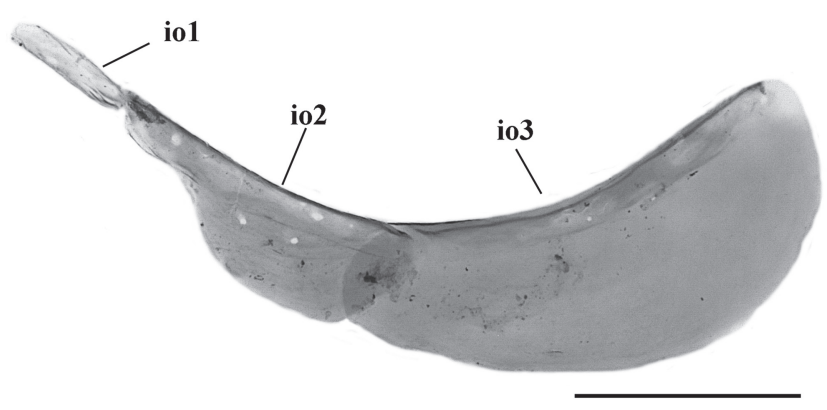

Fig. 2. Xenurobrycon varii, MPEG 26592, $12.5 \mathrm{~mm} \mathrm{SL}$, right side (inverted) of infraorbital (io) series. Antorbital not depicted. Scale bar $=500 \mu \mathrm{m}$.

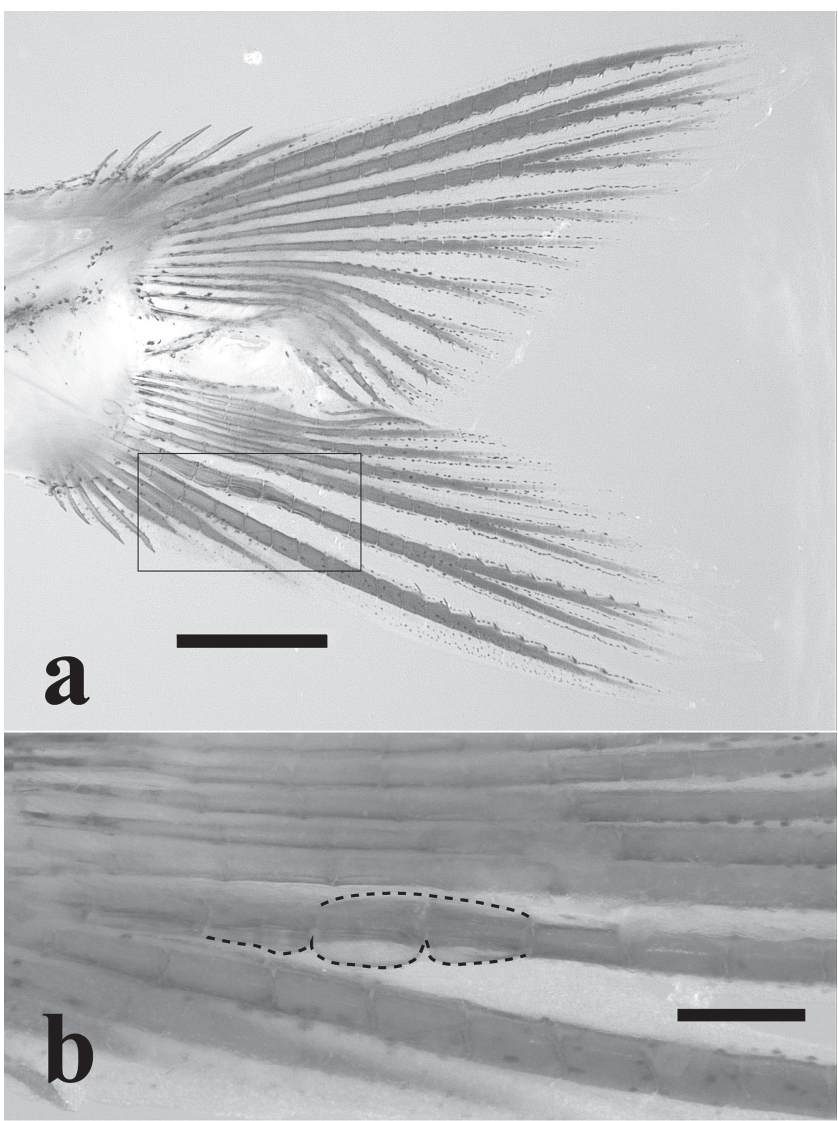

Fig. 3. Xenurobrycon varii, MPEG 26591, male, $15.0 \mathrm{~mm}$ $\mathrm{SL}$, left side of caudal-fin rays (pouch-scale removed): (a) bilateral, antrorse hooks, usually one pair per lepidotrichium segment (rectangle indicates magnified area represented in b); (b) set of lamellar processes on eighth principal caudal-fin ray of lower lobe, dashed lines represent the delimitation of left elements of paired ventral processes and dorsal unpaired process along ray segments 3 to 5 and 4 to 5 , respectively. Scale bars $=1 \mathrm{~mm}$ and $0.25 \mathrm{~mm}$ respectively.

Description. Morphometric data for examined specimens in Table 1. Body profile convex along dorsal portion from tip of snout to posterior end of supraoccipital spine; slightly convex from that point to dorsal-fin origin (more prominent in females) approximately straight along dorsal-fin base, and becoming almost completely straight from terminus of dorsal-fin to first dorsal procurrent caudal-fin ray. Ventral profile of head convex from lower lip to pectoral-fin origin. Ventral profile of body slightly convex from that point to anterior margin of urogenital papillae, straightening out along anal-fin base, and becoming slightly convex from anal-fin terminus to first ventral procurrent caudal-fin rays.

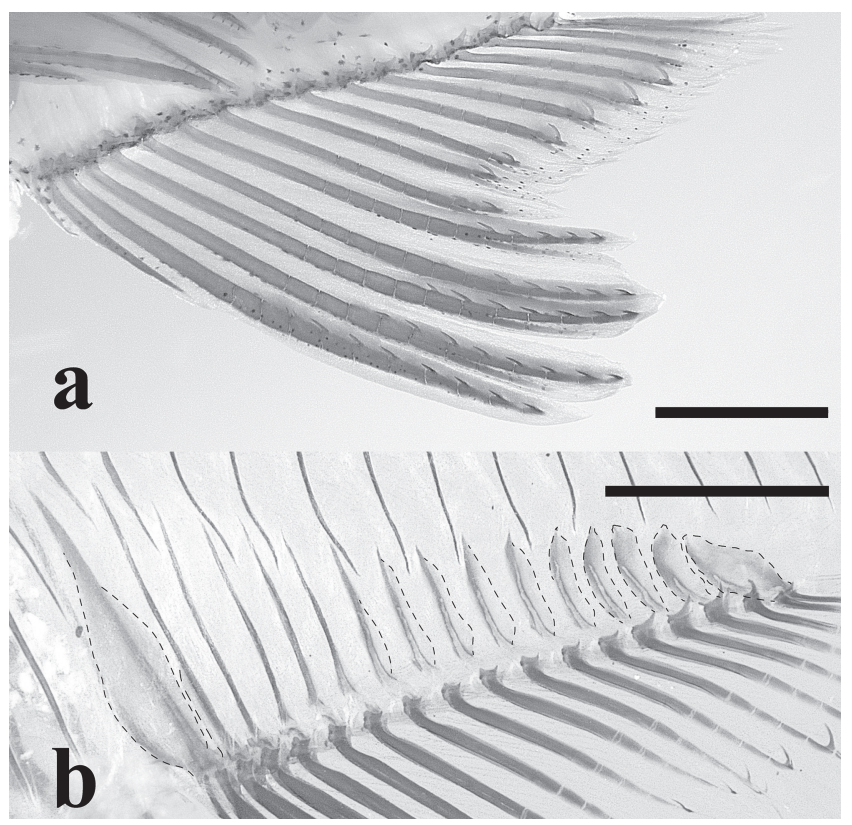

Fig. 4. Xenurobrycon varii, anal-fin rays: (a) left side, MPEG 26591, male, $15.0 \mathrm{~mm} \mathrm{SL}$, with bilateral, antrorse hooks; (b) right side (inverted), MPEG 26592, male, $13.5 \mathrm{~mm}$ SL, with well-developed lamellar process on pterygiophores. Scale bars $=1 \mathrm{~mm}$ and $0.25 \mathrm{~mm}$ respectively.

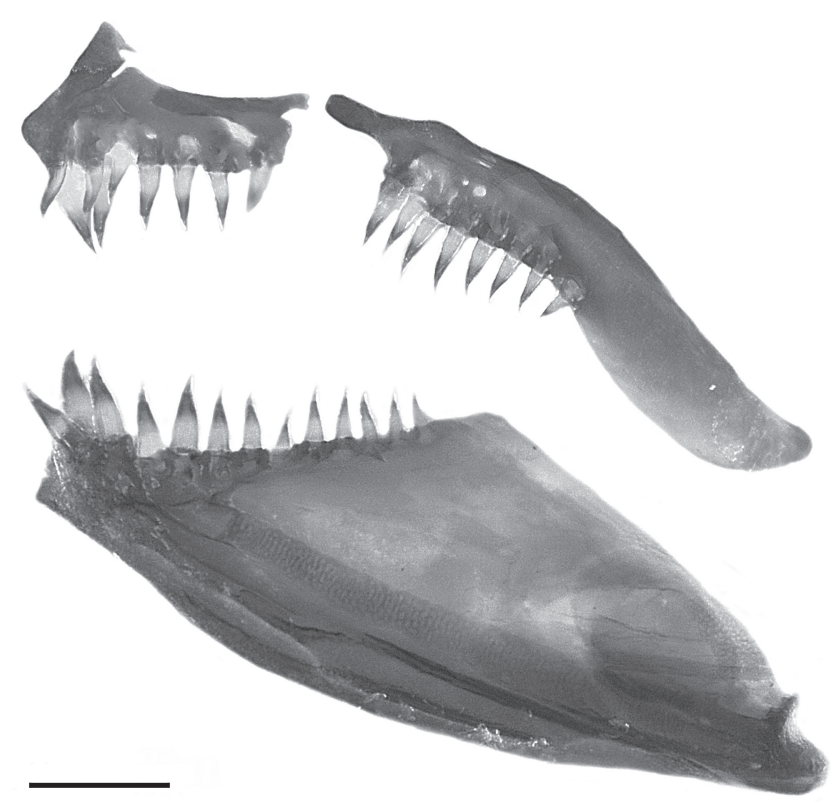

Fig. 5. Xenurobrycon varii, MPEG 25239, $13.4 \mathrm{~mm}$ SL, left side of maxilla and premaxilla and right side (inverted) of dentary, Scale bars $=0.2 \mathrm{~mm}$. 
Table 1. Morphometric data of Xenurobrycon varii. Values for the holotype included in number of specimens and range of values. Max $=$ maximum; Min $=$ minimum; $\mathrm{N}=$ number of specimens; $\mathrm{SD}=$ standard deviation.

\begin{tabular}{|c|c|c|c|c|c|c|}
\hline & Holotype & $\mathrm{N}$ & Min & $\operatorname{Max}$ & Mean & $\mathrm{SD}$ \\
\hline Standard length (mm) & 14.2 & 33 & 12.2 & 14.3 & - & - \\
\hline \multicolumn{7}{|c|}{ Percents of standard length } \\
\hline Depth at dorsal-fin origin & 23.3 & 33 & 20.0 & 25.2 & 22.6 & 1.5 \\
\hline Snout to dorsal-fin origin & 64.2 & 33 & 58.7 & 66.3 & 62.2 & 1.6 \\
\hline Snout to pectoral-fin insertion & 22.6 & 33 & 19.4 & 24.3 & 22.3 & 1.1 \\
\hline \multicolumn{7}{|l|}{ Snout to pelvic-fin insertion } \\
\hline Males & 32.5 & 17 & 28.0 & 36.0 & 31.5 & 2.1 \\
\hline Females & & 16 & 33.9 & 43.2 & 39.4 & 2.4 \\
\hline Snout to anal-fin origin & 59.3 & 33 & 52.2 & 60.9 & 56.5 & 1.6 \\
\hline \multicolumn{7}{|l|}{ Caudal-peduncle depth } \\
\hline Males & 13.4 & 17 & 8.1 & 13.4 & 12.0 & 1.4 \\
\hline Females & & 16 & 9.1 & 11.4 & 10.1 & 0.6 \\
\hline Caudal-peduncle length & 13.4 & 33 & 10.3 & 19.1 & 15.3 & 2.0 \\
\hline Pectoral-fin length & 21.2 & 33 & 12.2 & 23.8 & 18.1 & 3.1 \\
\hline \multicolumn{7}{|l|}{ Pelvic-fin length } \\
\hline Males & 35.3 & 17 & 32.2 & 38.9 & 36.1 & 2.2 \\
\hline Females & & 16 & 9.1 & 13.3 & 10.9 & 1.1 \\
\hline Dorsal-fin base length & 7.8 & 33 & 6.1 & 9.7 & 7.5 & 0.8 \\
\hline Dorsal-fin lenght & 19.8 & 33 & 13.4 & 22.2 & 17.2 & 2.4 \\
\hline Anal-fin base length & 24.0 & 33 & 21.0 & 26.9 & 23.6 & 1.5 \\
\hline \multicolumn{7}{|l|}{ Anal-fin lobe length } \\
\hline Males & 21.9 & 17 & 21.5 & 25.0 & 23.0 & 1.0 \\
\hline Females & & 16 & 9.6 & 20.1 & 15.2 & 2.9 \\
\hline Bony head length & 21.2 & 33 & 17.9 & 24.4 & 22.1 & 1.2 \\
\hline \multicolumn{7}{|c|}{ Percents of head length } \\
\hline Snout length & 19.4 & 33 & 14.3 & 25.0 & 18.6 & 2.5 \\
\hline Upper jaw length & 29.0 & 33 & 16.7 & 33.3 & 23.2 & 3.4 \\
\hline Horizontal eye diameter & 48.4 & 33 & 36.7 & 58.3 & 48.3 & 4.0 \\
\hline Least interorbital distance & 32.3 & 33 & 26.7 & 37.9 & 31.3 & 3.4 \\
\hline
\end{tabular}

Mouth terminal; upper and lower jaws of equal length. Teeth conical with slightly posteriorly recurved tips. Premaxillary teeth $8(2), 9(4), 10(2)$ or 11(3). Maxillary teeth 7(6) or 8(6). Posterior tip of maxilla reaching anterior margin of lateral ethmoid. Dentary teeth 11(3) or 12(1); second and sometimes third tooth anterodorsally aligned. Branchiostegal rays 4(12); first to third attached to anterior ceratohyal and fourth attached to cartilage between anterior and posterior ceratohyal $(\mathrm{n}=8)$ or to posterior ceratohyal $(\mathrm{n}=4)$. Only antorbital and infraorbitals 1, 2 and 3 present. Supraorbital, pterotic laterosensory canal and epioccipital bridge absent. Extrascapular and posttemporal bones absent. Supracleithrum laterosensory canal absent.

Scales cycloid, with few or no radii on posterior margin, except for pouch scale and scales between pelvic-fin origins (See "Sexual Dimorphism"). Predorsal scales 15(3), 16(16), $17 *(12)$ or $18(2)$. Lateral line longitudinal series with $30(1)$, 31(3), 32(5), 33(5), 34*(8), 35(3), 36(4), 37(2) or 38(2) scales, of which $3(2), 4(10), 5^{*}(10), 6(7)$ or $7(3)$ are perforated. Circumpeduncular scales 10(3), 11(4), 12*(25) or 13(1). Scale rows between dorsal- and anal-fin origins $8(1), 9 *(11)$, 10(17) or 11(4).

Pectoral-fin rays i,7(8) or i, $8 *(25)$. Tip of pectoral fin reaching slightly beyond vertical through pelvic-fin origin in females; total pelvic-fin rays $7 *(28)$ or $8(5)$ (see "Sexual Dimorphism"). Supraneurals absent. Dorsal-fin rays ii,6(6) or ii, $7^{*}(27)$. First dorsal-fin pterygiophore inserted immediately posterior to neural spine of $15^{\text {th }}(6)$ or $16^{\text {th }}(6)$ centrum. Dorsal-fin origin immediately posterior to anal-fin origin. Adipose fin absent. Anal-fin rays iii,13(2), iii,14(5), iii,15*(9), iii,16(12) or iii,17(5). First anal-fin pterygiophore inserted immediately posterior to haemal spine of $13^{\text {th }}(11)$ or $14^{\text {th }}(1)$ centrum. Mature males with anal-fin lobe longer than that of females and bilateral hooks on branched and unbranched rays (see "Sexual Dimorphism"). Principal caudal-fin rays 10/9; highly modified, and with bony hooks (see "Sexual Dimorphism"). Dorsal caudal-fin procurrent rays 5(10) or 6(2); ventral caudal-fin procurrent rays 6(9) or 7(3). Precaudal vertebrae 12(12). Caudal vertebrae 24(9) or 25(3).

Color in alcohol. Body pale yellow with small chromatophores on posterior margin of scales. Chromatophores highly concentrated on lips, but more disperse on dorsal portion of head, infraorbital and mandibular areas. Postorbital area with scattered chromatophores, more concentrated anteriorly to dark longitudinal stripe. Narrow, dark longitudinal stripe extending from fifth or sixth longitudinal scale to end of caudal peduncle. Narrow, dark dorsal stripe extending from posterior margin of supraoccipital to dorsal caudalfin procurrent rays, whitish at dorsal fin base. Narrow, dark ventral stripe from first anal-fin ray to ventral caudal-fin procurrent rays. Usually, only base of first pectoral-fin ray, and rarely others, pigmented. Dorsal, anal and posterior half of caudal-fin rays densely pigmented.

Sexual dimorphism. Anal-fin base slightly concave in females, and nearly straight in males. Number of scales between pelvic-fin insertions in mature males $5(7)$ or 6(4), in females 1(6) or 2(4). Scales between mesial pelvic-fin rays larger with more radii than other body scales (except for pouch scale) in mature males, and equal in size in females and juveniles. Number of scales between mesial pelvic-fin rays 2(2) or 3(9) in mature males (a single male with one large scale, almost as large as the pouch scale), and 1(10) in females. Pouch scale somewhat teardrop shaped, similar to that of X. polyancistrus (Weitzman 1987: fig. 3) but with numerous, loosely positioned radii extending over posterior, posterodorsal, and posteroventral margins, being more numerous on latter portion.

Tip of pectoral fin at vertical through $9^{\text {th }}(11)$ or $11^{\text {th }}(1)$ scale of lateral line longitudinal series in mature males, whereas in females and juveniles, tip of pectoral fin located 
at vertical through $11^{\text {th }}(7)$ scale. Pelvic fin hyaline in females and juvenile specimens inserted at vertical through $10^{\text {th }}(9)$ scale of lateral line longitudinal series, with vii(16) rays. In mature males, pelvic fin pigmented from first to fourth, or sometimes fifth ray, inserted at vertical through $5^{\text {th }}(11)$ or $7^{\text {th }}$ (1) scale of lateral line longitudinal series; pelvic-fin rays i,6(1), ii, $5^{*}(11)$ or ii,6(5). Mature males with two unpaired antrorse hooks per segment on ventral margin of unbranched and branched pelvic-fin rays; hooks increasing in size until middle of hooked portion, then decreasing distally; hooks on first unbranched ray larger than on branched ones. Anterior tip of pelvic bone located anterior to vertical through pectoralfin rays insertion (5), posterior tip of pelvic bone between $2^{\text {nd }}$ and $3^{\text {rd }}(5)$ ribs in mature males. In female and juvenile specimens, anterior tip of pelvic bone between $1^{\text {st }}$ and $2^{\text {nd }}(6)$ ribs, posterior tip of pelvic bone at $3^{\text {rd }}(2)$ or between $3^{\text {rd }}$ and $4^{\text {th }}(4)$ ribs. Pelvic -fin of mature males significantly longer than in females $(32.2-38.9 \%$ SL vs. 9.1-13.3\% SL $\mathrm{p}<0.001$; Fig. 6). Distance between snout to pelvic-fin insertion between male and female or juvenile specimens (28.0-36.0\% SL vs. 33.9-43.2\% SL; Fig. 7) not significantly different.

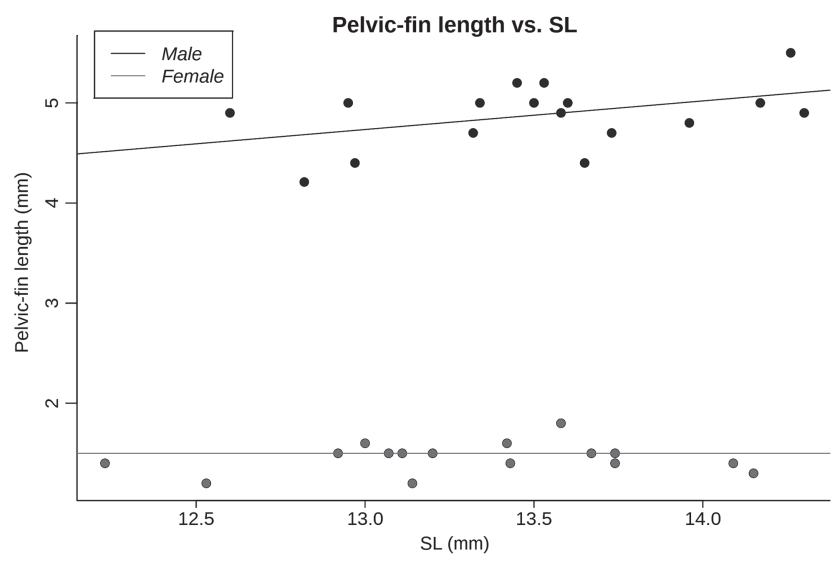

Fig. 6. ANCOVA plot showing the difference between pelvic-fin length of mature males and females of Xenurobrycon varii.

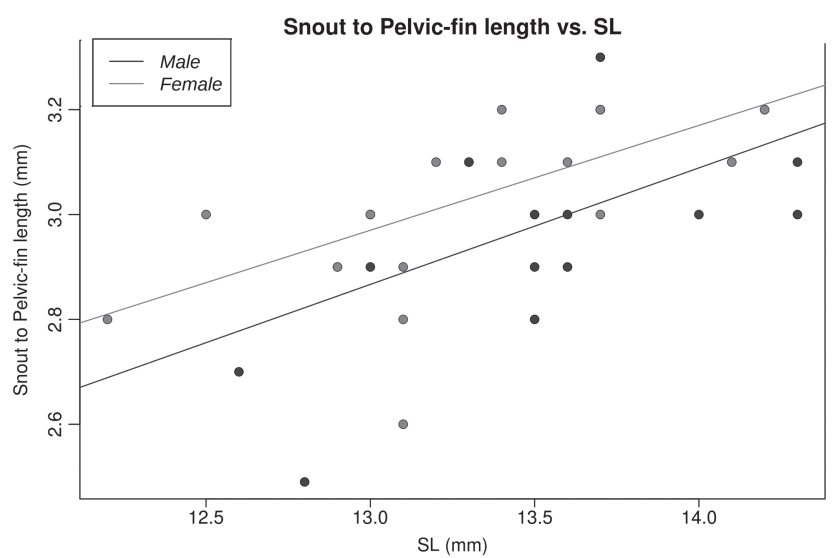

Fig. 7. ANCOVA plot showing relation between snout to pelvic-fin length and SL of mature males and females of Xerunobrycon varii.
Anterior anal-fin lobe formed by $3^{\text {rd }}$ unbranched ray and anteriormost four branched rays (Fig. 4a), longer in mature males than in females. Lamellar process of pterygiophores well developed in $1^{\text {st }}$ proximal radial, gradually increasing in size from $7^{\text {th }}$ to $16^{\text {th }}$ or $17^{\text {th }}$ proximal radials but poorly developed or, absent from $2^{\text {nd }}$ to $6^{\text {th }}$ pterygiophores (Fig. 4b). Bilateral, antrorse anal hooks located from $3^{\text {rd }}$ unbranched ray to $8^{\text {th }}$ branched rays, and strongly recurved hooks on branched rays $9^{\text {th }}-12^{\text {th }}$; usually one pair on each segment. Anal hooks roughly equal in size, but larger on posteriormost rays. Caudal-fin musculature of mature males same as that described for X. macropus (Weitzman \& Fink, 1985: 77, 81-83, and fig. 11). Caudal-fin rays with bilateral antrorse hooks, usually one pair per lepidotrichia segment; approximately equal in size on most rays but lager on unbranched rays (Fig. 3a). In mature males, set of lamellar processes present on eighth principal caudal-fin ray of lower lobe composed by ventral, paired lamellar expansions on $3^{\text {rd }}$ to $5^{\text {th }}$ lepidotrichia segments, and an unpaired lamellar expansion from $4^{\text {th }}$ to $5^{\text {th }}$ lepidotrichia segments (Fig. 3b).

Distribution. Xenurobrycon varii is known from tributary streams of rio Tapajós and rio Jamanxim (Fig. 8).

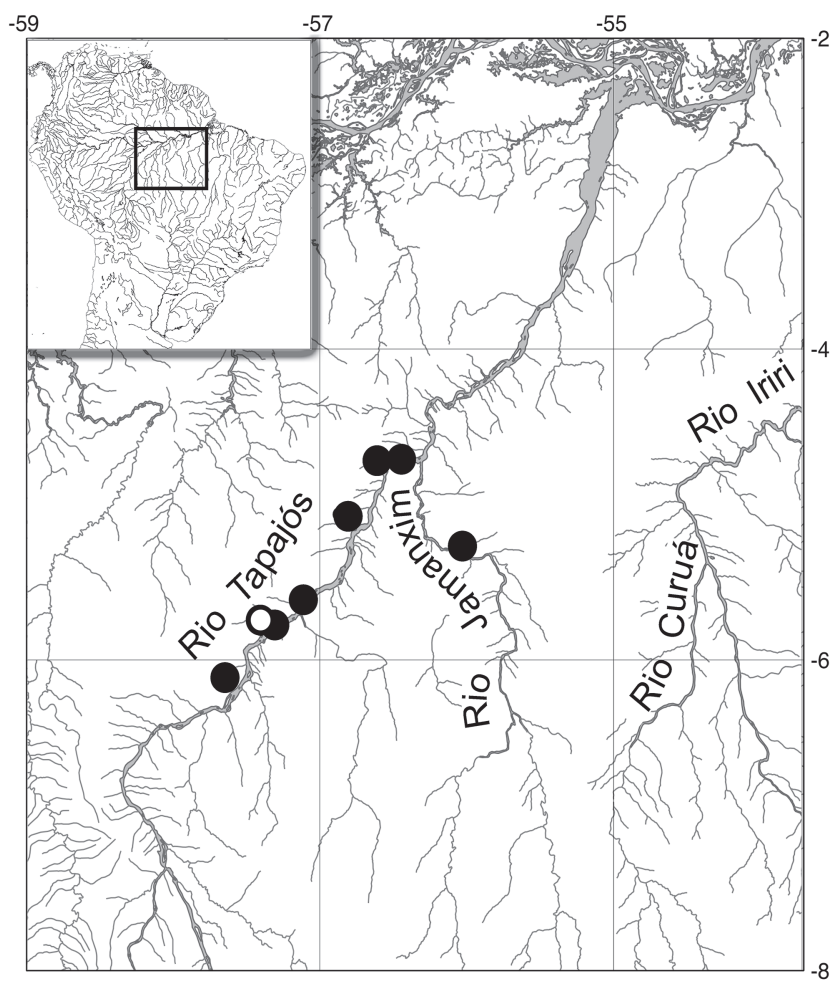

Fig. 8. Map of portion of rio Tapajós basin, and adjoining areas, showing collecting sites (dark circles) and the type locality (white circle) of Xenurobrycon varii.

Etymology. This species is named in honor of Richard P. Vari, an esteemed person and ichthyologist, for his contributions to the systematics of fishes and his continuous support and aid to the authors. 
Conservation status. Considering that present relevant threats to the species were not detected in its distribution area, Xenurobrycon varii could be classified as Least Concern (LC), according to the International Union for Conservation of Nature (IUCN) categories and criteria (IUCN Standards and Petitions Subcommittee, 2014). On the other hand, at least five major hydroelectric power plants denominated Complexo Tapajós (São Luiz do Tapajós, Jatobá, Cachoeira dos Patos, Cachoeira do Caí and Jamanxim) are expected to be built in the occurrence area of the species by the Brazilian government, causing highly plausible impacts to the population of Xenurobrycon varii, leading to a revaluation of the conservation status of the species, along with others, in the medium term.

\section{Discussion}

Xenurobrycon varii processes all eight synapomorphies recognized for that genus by Weitzman \& Fink (1985), justifying its inclusion in Xenurobrycon. Similarly to its congeners, $X$. varii is a miniature species (sensu Weitzman $\&$ Vari, 1988), with the largest known specimen reaching $17.3 \mathrm{~mm}$ SL. In addition to their diminutive size, the lack of infraorbital bones 4 and 5 in $X$. varii might also be associated with miniaturization events, as suggested by Weitzman \& Vari (1988) and further discussed by ToledoPiza et al. (2014) and Mattox et al. (2016). Comparatively, the infraorbital series is almost complete in $X$. heterodon, $X$. macropus, X. pteropus and X. polyancistrus, which present infraorbitals 1 to 5 (Moreira, 2005). On the other hand, $X$. coracoralinae shares with $X$. varii, the lack of those bones, but also lacks infraorbital 1, a unique condition among Xenurobrycon species (Moreira, 2005)

The presence of a set of lamellar processes on segments 3-5 on the eighth ray of the caudal-fin lower lobe (see "Sexual Dimorphism") is an unusual feature among xenurobyconin species. Besides $X$. varii, similar structures were found only in $X$. coracoralinae and $X$. macropus, however, in the latter species the dorsal, unpaired process is lacking, and the paired, ventral processes are distinctly larger, forming a conspicuous flange-like process that extends across two segments, as described in Weitzman \& Fink (1985: fig. 11). Despite Moreira (2005) reported the absence of the flange-like process in $X$. coracoralinae, analyses of paratypes of that species (MNRJ 24887) revealed the presence of these processes on the eighth ray of the caudal-fin lower lobe. Xenurobrycon heterodon, X. pteropus, and X. polyancistrus lack any of these processes. Xenurobrycon varii shares the presence of a teardrop shaped pouch scale with $X$. coracoralinae, $X$. heterodon and $X$. polyancistrus (Weitzman, 1987: fig. 3). In contrast, X. macropus and $X$ pteropus have more rounded pouch scales, with short blunt posterior protuberances (Weitzman \& Fink, 1985: fig. 28) and numerous ventral radii in the later (Weitzman $\&$ Fink, 1985: fig. 29). Such conditions contradict, at least in part, the idea that $X$. varii would share a close common history with $X$. macropus, but seem to be an additional indicative of its closely relatedness to $X$. coracoralinae. However, despite the aforementioned considerations, the relationships among Xerunobrycon species remains to be investigated, since this point is out of the scope of the present contribution.

\section{Key to the species of Xenurobrycon}

1a. Adipose fin present........... pteropus (rio Solimões basin) 1b. Adipose fin absent. .. 2

2a. Jaws teeth unicuspid, bicuspid, and tricuspid $X$. heterodon (Upper rio Amazonas basin)

2 b. Jaws teeth exclusively conical ...................................... 3

3a. Infraorbitals 4 and 5 present...................................... 4

3b. Infraorbitals 4 and 5 absent ........................................ 5

4a. Anal-fin hooks of mature males larger posteriorly ........ X. polyancistrus (rio Mamoré basin)

4b. Anal-fin hooks of mature males similar in size or decreasing posteriorly.....X. macropus (rio Paraguai basin)

5a. Posterior half of both caudal-fin lobes darkened; hooks on last unbranched plus 9-12 anal-fin rays; infraorbital 1 present ..................................... varii (rio Tapajós basin)

5 b. Posterior half of both caudal-fin lobes hyaline; hooks on anal-fin rays only on last unbranched and $4^{\text {th }}-5$ th branched rays; infraorbital 1 absent X. coracoralinae (rio Araguaia basin)

Comparative material examined. Argopleura magdalenensis: Colombia: USNM 220369, 9 (2 c\&s), 41.9-47.2 mm SL, río Calondaima, río Magdalena basin. Iotabrycon praecox: Ecuador: USNM 216803, 13 (2 c\&s), 15.7-17.6 mm SL, Centro Cientifico Río Palenque. Scopeocharax atopodus: Peru: MZUSP 110584, 4, 19.220.7 mm SL, Huánuco, río Oro, río Huallaga. Scopeocharax rhinodus: Peru: MZUSP 110537, 10 of 24, 19.1-29.6 mm SL, Huánuco, río Oro, río Huallaga. Scopeocharax sp.: Peru: USNM 329756, 22 (2 c\&s), 25.4-29.8 mm SL, San Martin, río Cumbaza. Tyttocharax tambopatensis: Peru: USNM 323417, 4 c\&s of 20, 11.5-13.7 mm SL, paratypes, Madre de Dios, Parque Nacional Manu, Aguajal stream. Xenurobrycon coracoralinae: Brazil: MNRJ 24887, 47 (3 c\&s), 10.3-15.2 mm SL, paratypes, Mato Grosso, Alto da Boa Vista, rio Araguaia. Xenurobrycon heterodon: Colombia: USNM 280246, 5 (2 c\&s), 17.5-20.5 mm SL, Caquetá, río Orteguaza. Xenurobrycon macropus: Paraguay: MZUSP 54151, 20 of 125, 14.9-15.8 mm SL, Concepción, río Apa. USNM 219382, 2 c\&s, 13.8-15.8 mm SL, lago Ypacari. Xenurobrycon polyancistrus: Brazil: MZUSP 96882, 9, 12.7-14.4 mm SL, Mato Grosso, rio Culuene. Bolivia: USNM 278191, 2 c\&s of 5, 12.9-14.2 mm SL, paratypes, Laguna Moacusal, río Isiboro. Xenurobrycon pteropus: Brazil: MZUSP 96321, 5, 12.114.6 mm SL, Amazonas, rio Solimões. USNM 232921, 1 c\&s, 11.7 $\mathrm{mm}$ SL, paratype, Amazonas, igarapé Fonte Boa.

\section{Acknowledgements}

The authors are grateful to three anonymous referees 
for critical review of the manuscript; Cristiano Moreira and Marcelo Britto (MNRJ), Wolmar Wosiacki (MPEG), Osvaldo Oyakawa, Aléssio Datovo, João Genova and Michel Gianeti (MZUSP), and Richard Vari (USNM) for assistance with specimen loans and/or visits to their respective institutions; Marcelo Sturaro for aid in preparation of Figure 1, Alexandre Bonaldo and Yulie Shimano (MPEG) for aid in preparation of Figure 2, and Níthomas Feitosa for aid in preparation of Figures 3, 4, and 5; Gustavo Ballen for aid in statistics analyses; Jeremy Dickens for language review. Authors were financially supported by Fundação de Amparo à Pesquisa do Estado de São Paulo (FAPESP, proc. 2013/09926-3 - LAWP), and Conselho Nacional de Desenvolvimento Científico e Tecnológico (CNPq proc. 313404/2015-1 - Programa de Capacitação Institucional-MPEG ALN-F; 150400/2015-2 GMD; 141482/2014-1 - MBM). This contribution was also supported by the South American Characiformes Inventory Project (FAPESP proc. 2011/50282-7).

\section{References}

Dragulescu, A. A. 2014. Xlsx: Read, write, format Excel 2007 and Excel 97/2000/XP/2003 files. R package (Version 3.1.1.) [Software]. Available from http://CRAN.Rproject.org/ package $=x l s x /(22$ September 2015).

Ferraris Jr., C. J. 2007. Checklist of catfishes, recent and fossil (Osteichthyes: Siluriformes), and catalogue of siluriform primary types. Zootaxa, 1418: 1-628.

Fink, W. L. \& S. H. Weitzman. 1974. The so-called cheirodontin fishes of Central America with descriptions of two new species (Pisces: Characidae). Smithsonian Contributions to Zoology, 172: 1-46.

IUCN Standards and Petitions Subcommittee. 2014. Guidelines fro using the IUCN Red List Categories and Criteria. Version 11. Prepared by the Standards and Petitions Subcommittee. available from http://www.iucnredlist.org/documents/ RedListGuidelines.pdf (Date of access - 29 February 2016).

Kloke, J. D. \& J. W. McKean. 2012. Rfit: rank-based estimation for linear models. The R Journal, 4: 57-64.

Kloke, J. D. \& J. W. McKean. 2014a. Npsm: Package for Nonparametric Statistical Methods using R. R package version v.3.1.1. Available from https://cran.r-project.org/web/ packages/npsm/ (22 September 2015).

Kloke, J. D. \& J. W. McKean. 2014b. Nonparametric statistical methods using R. 2nd Edition. Boca Raton, CRC Press, 271p.

Mattox, G. M. T., R. Britz, M. Toledo-Piza. 2016. Osteology of Priocharax and remarkable developmental truncation in a miniature Amazonian fish (Teleostei: Characiformes: Characidae). Journal of Morphology, 277: 65-85.
Moreira, C. R. 2005. Xenurobrycon coracoralinae, a new glandulocaudine fish (Ostariophysi: Characiformes: Characidae) from central Brazil. Proceedings of the Biological Society of Washington, 188: 855-862.

R Core Team. 2015. R: A language and environment for statistical computing (Version 3.1.1) [Software], R Foundation for Statistical Computing, Vienna. Available from http://www.Rproject.org/ (29 September 2015).

Taylor, W. R. \& G. C. Van Dyke. 1985. Revised procedures for staining and clearing small fishes and other vertebrates for bone and cartilage study. Cybium, 9: 107-119.

Thomaz, A. T, D. Arcila, G. Ortí \& L. R. Malabarba. 2015. Molecular phylogeny of the subfamily Stevardiinae Gill, 1858 (Characiformes: Characidae): classification and the evolution of reproductive traits. BMC Evolutionary Biology, 15: 1-25.

Toledo-Piza, M., G. M. T. Mattox \& R. Britz. 2014. Priocharax nanus, a new miniature characid from the rio Negro, Amazon basin (Ostariophysi: Characiformes), with an updated list of miniature Neotropical freshwater fishes. Neotropical Ichthyology, 12: 229-246.

Weitzman, S. H. 1987. A new species of Xenurobrycon (Teleostei: Characidae) from the río Mamoré basin of Bolivia. Proceedings of the Biological Society of Washington, 100: 112-120.

Weitzman, S. H. \& S. V. Fink. 1985. Xenurobryconin phylogeny and putative pheromone pumps in glandulocaudine fishes (Teleostei: Characidae). Smithsonian Contributions to Zoology, 421: 1-121.

Weitzman, S. H. \& N. A. Menezes. 1998. Relationships of the tribes and genera of the Glandulocaudinae (Ostariophysi: Characiformes: Characidae) with a description of a new genus, Chrysobrycon. Pp. 171-192. In: Malabarba, L. R., R. E. Reis, R. P. Vari, Z. M. S. Lucena \& C. A. S. Lucena (Eds.). Phylogeny and classification of Neotropical fishes. Porto Alegre, Edipucrs.

Weitzman, S. H. \& R. P. Vari. 1988. Miniaturization in South American freshwater fishes; an overview and discussion. Proceedings of the Biological Society of Washington, 101: 444-465.

Weitzman, S. H., S. V. Fink, A. Machado-Allison \& R. Royero. 1994. A new genus and species of Glandulocaudinae (Teleostei: Characidae) from southern Venezuela. Ichthyological Exploration of Freshwaters, 5: 45-64. 